\title{
Abstracts of the ASHS Northeast Region Annual Meeting
}

\author{
Sainte-Foy, Québec, Canada
}

7-8 Jan. 1994

\section{Fruit Crops}

\begin{abstract}
GAMETOPHYTIC SELECTION OF THE FUSED VEIN TRAIT IN SQUASH

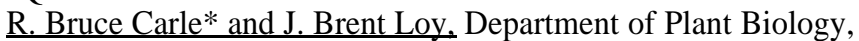
Nesmith Hall, University of New Hampshire, Durham, NH 03824

Three experiments were conducted to delineate gametophytic selection of the fused vein trait in Cucurbita pepo L. Gametophytic subvitality was verified by comparing fused vein and normal pollen tube growth. Microscopic examination of partitioned, co-pollinated flowers revealed fewer and slower growing fused vein tubes than normal. The effects of gametophytic subvitality on seed yield and inheritance were shown by manipulating the severity of reproductive competition. Fused vein, normal, and $\mathrm{F}_{1}$ lines were pollinated with fused vein, normal, 50:50 mix, and $F_{1}$ pollen at three different pollen loads. Analysis showed that fused vein pollen generated significantly fewer seed per fruit in all lines. In ensuing $\mathrm{F}_{2}$ and testcross populations, a reduction in load and thus competition significantly increased the number of fused vein individuals. Leaf number and area for normal, fused vein, $\mathrm{F}_{1}, \mathrm{~F}_{2}$, and testcross plants were assessed to test pleiotropic effects on growth common to gametophytic subvitals. Although normal and fused vein lines differed in leaf number and size, their total leaf areas were not significantly different. $F_{2}$ and testcross plants showed no difference between normal and fused vein individuals; leaf size and number were independent of leaf morphology.
\end{abstract}

\section{FLESH COLOR AS A PEACH MATURITY INDEX}

Walter Boswell*, Bernard Bible, and Suman Singha, Department of Plant Science, University of Connecticut, Storrs, CT 06269-4067

Flesh color has been proposed as a maturity index for peaches. The objective of the present study was to determine the effectiveness of this parameter in 'Loring', 'Jersey Dawn', 'Madison', and 'Raritan Rose' peach (Prunus persica L. Batsch). Fruit were picked at weekly intervals at three or four harvest dates, with five fruit per cultivar being picked from each of three trees. Flesh firmness and soluble solids were measured immediately following harvest, and CIELAB coordinates $\left(\mathrm{L} * \mathrm{a}^{*} \mathrm{~b} *\right)$ of blush and flesh color were determined with a Minolta CR$200 \mathrm{~b}$ calorimeter. There was a highly significant correlation $(P<$ 0.001 ) between firmness and flesh hue angle for all four cultivars and with flesh chroma especially for the white-fleshed 'Raritan Rose'. The correlation values between firmness and blush hue angle were consistently lower. Soluble solids did not consistently correlate with flesh or blush color. Even though blush color influences consumer preference, it was not as good an indicator of maturity as flesh color for the cultivars that we tested.
INHERITANCE AND HERITABILITY OF SEED SIZE IN HULLLESS SEEDED STRAINS OF CUCURBITA PEPO

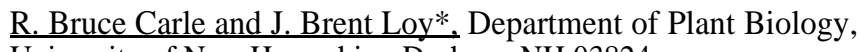
University of New Hampshire, Durham, NH 03824

Genetic experiments were initiated to assess the potential for combining large seed size from PI 285611, a large-fruited, hullless seeded accession, with small fruit size from a hullless seeded breeding line (NH29-13-5-4). An F population and parental line were fieldgrown during Summer 1993 to determine inheritance and heritability of large seed size and the relation between fruit and seed size. Seed size variables of weight, width, length, and thickness were regressed against fruit weight. There was a moderate, positive correlation between large fruit and seed length $\left(R^{2}=0.46\right)$. However, seed thickness, a major determinant of seed weight, was not correlated with fruit size. In an $\mathrm{F}_{2}$ population of $\approx 450$ plants, there was a small number of plant selections with fruit under $1.5 \mathrm{~kg}$ and seed size approaching that of PI 285611.

\section{A BIOECONOMIC MODEL OF MELON PRODUCTION FOR MULCH AND ROWCOVER MANAGEMENT}

Sylvie Jenni* and Katrine A. Stewart. Macdonald Campus of McGill University, Ste. Anne de Bellevue, Quebec H9X 3V9, Canada

Quebec vegetable growers are increasingly using agricultural plastics (plasticulture) not only for gains in crop yield, earliness, and quality, but also for weed control and water and fertilizer conservation. Curcubitaceae include heat-loving crops that respond well to plasticulture. Melons are among the most responsive of all crops because they are sensitive to both low soil and air temperatures and to wind, but are very tolerant of high temperatures. The objective of this project was to develop a bioeconomic model that will predict the yield and timing of a melon crop under a number of mulch/tunnel combinations, evaluate the profitability of each production regime, and establish the optimal combinations that will maximize profit and continuity of supply over an extended growing season. A compartment model representing state, rate, and driving variables will be presented.

FIELD EVALUATION OF FACTORS CONTRIBUTING TO STRAWBERRY BLACK ROOT ROT DISEASE

Katherine B. Wing* and Marvin P. Pritts, Cornell University, Department of Fruit and Vegetable Science, 134-A Plant Science Building, Ithaca, NY 14853-5908

Black root rot is a devastating, poorly understood disease complex affecting strawberries in temperate regions. The objective of the study was to conduct a comprehensive field survey of environmental, cultural, and pathological factors contributing to black root rot disease of strawberries as it occurs in New York. In Spring 1992, growers were visited to collect information on cultural practices, field measurements, and plant and soil samples from healthy and infected fields. Plants were scored for root health and measurements were made for nematode densities, soil compaction, soil texture, soil nutrients, and plant dry weights. Variables significantly correlated with poor root health were soil compaction, fine soil texture, absence of raised beds, high rates of terbacil (Sinbar) use, advanced age of planting, and many cumulative years of strawberry culture. 
EFFECTS OF SOIL MANAGEMENT ON TREE GROWTH, FRUIT SET, YIELD, AND FRUIT QUALITY OF SPARTAN APPLES ON M.9 ROOTSTOCK

Martin Paré and Deborah Buszard, Department of Plant Science, Macdonald Campus of McGill University, Ste-Anne-de-Bellevue, Québec H9X 3V9, Canada

Four soil management treatments were applied from 1991 to 1993 to 'Spartan'/M.9 apple trees planted in 1987. Geotextile, straw mulch, composted manure mulch, and grass sod were used to control weed growth in a 1-m-wide band under the trees. The experiment was a randomized complete block design with two blocks and seven trees per treatment; data was taken from the five inner trees in each plot. Trees in straw mulch showed the largest increase in trunk cross-sectional area $(+45.6 \%)$ over the three years; those in the geotextile showed the second largest $(40.7 \%)$. Straw mulch also resulted in the largest yield 2 years out of 3 . Fruit set and fruit quality were also assessed, and trees in manure mulch and grass sod set the least fruit in each season. Fruit from the grass sod treatment remained harder in storage, and both straw mulch and grass sod have a higher proportion of grade A fruit (57 of total fruit).

\section{DIAMMONIUM PHOSPHATE INCREASES YIELD OF LOW- BUSH BLUEBERRIES}

John M. Smagula* and Scott Dunham. Department of Plant, Soil, and Environmental Sciences, University of Maine, Orono, ME 044695722

Eight commercial lowbush blueberry fields received preemergent application of diammonium phosphate at $0,44.8$, or $89.6 \mathrm{~kg} \mathrm{P} / \mathrm{ha}$. Leaf samples taken in July of the application year showed a linear increase in $\mathrm{P}$ concentration with increasing DAP application. However, $\mathrm{P}$ concentrations in soil samples were not raised by DAP. Stem length, branching, and the number of flower buds per stem increased with DAP application. Yield, obtained by hand raking the $3 \times 9-\mathrm{m}$ treatment plots, increased with increasing rate of DAP. The average yield increase in response to 44.8 and $89.6 \mathrm{~kg} \mathrm{P} / \mathrm{ha}$ from DAP was 824 and $1679 \mathrm{~kg} / \mathrm{ha}$, respectively.

EFFECTS OF WARMING DURING STORAGE ON ACCUMULATION AND OXIDATION OF $\propto-$ FARNESENE, AND ON SCALD DEVELOPMENT ON APPLES

Zhanyuan Du and William J. Bramlage*. Department of Plant and Soil Sciences, University of Massachusetts, Amherst, MA 01003-0910

When Cortland apples were stored at 0 and 20C, OC reduced ethylene production and increased accumulations of $\propto-$ farnesene and conjugated trienes (CTs) in fruit peel, but it resulted in a lower CT258 : CT281 ratio than did 20C. At 20C no fruit developed scald, but at 0C, $84 \%$ of the fruit scalded. When fruit were stored at $0 \mathrm{C}$ but transferred to $20 \mathrm{C}$ for 5 days after 0 to 8 weeks at $0 \mathrm{C}$, only transfer after 2 or 4 weeks reduced scald. During warming, ethylene production and accumulations of $\propto$-farnesene and CTs increased, but after 20 weeks of storage, when scald developed, warming at 2 and 4 weeks reduced CT281 and increased the CT258 : CT281 ratio. Warming at other intervals had no effect.

EARLY PERFORMANCE OF FOUR APPLE CULTIVARS GRAFTED ON THE MICROPROPAGATED OTTAWA THREE ROOTSTOCK AND TRAINED IN TWO SYSTEMS

Raymond L. Granger*. Shahrokh Khanizadeh. and Yvon Groleau. Agriculture Canada, Research Station, St-Jean-sur-Richelieu, Québec J3B 3E6, Canada

In experimental plots established in 1989, 'Spencer', 'Empire', 'MacSpur', and 'Lobo' trees grafted on the in vitro-propagated Ottawa $3(0.3)$ rootstock were trained in the triple axis and in the slender spindle systems. They were planted at 5 (between rows) $\times 2.04 \mathrm{~m}$ and laid out in a split plot array with four replicates. There were five trees per subplot unit. All trees were trickle-irrigated every year. Fruit thinning was chemically done for the first time in 1993. Trees from this experiment came into bearing in 1991, and their total cumulative yield was significantly superior in the case of trees of the Spindlebush system. Since no interactions were found, we cannot conclude that any given combination is better than the others. 'Lobo', which has averaged nearly 21 tonnes/ha per tree, was best in terms of total cumulative yield and also in terms of yield efficiency. 'MacSpur' and 'Empire' were the second best ones in yield efficiency, and 'Spencer' was significantly lower. Fruit size was very good for all combinations in 1993. At their fifth-leaf stage in 1993, the yield of 'Empire' trees from this experiment was higher by an average of more than $1 \mathrm{~kg}$ per tree than that of comparable trees of conventionally propagated O.3 trees planted in adjacent test plots. The tree vigor of the micropopagated 0.3 trees was better than that of the conventionally propagated ones as revealed by the trees' trunk and canopy development. However, a few trees exhibited slight burr-knot growth on their trunk. This has never been observed on the conventionally propagated 0.3 rootstock.

\section{Growth Media}

\section{KENAF AS A COMPONENT OF GROWTH MEDIA}

Wallace G. Pill, Department of Plant and Soil Sciences, University of Delaware, Newark, DE 19717-1303

Kenaf core (xylem) particles (2 to $4 \mathrm{~mm}$ in diameter) were submersed in ammonium nitrate solutions (0 to $5000 \mathrm{mg} \mathrm{N} / \mathrm{liter}$ ) for 5 days. The kenaf was incorporated into complementary components as $30 \%$ kenaf: $70 \%$. sphagnum moss or $10 \%$ kenaf: $10 \%$ vermiculite : 10\% calcined clay : $70 \%$ sphagnum moss. These media received standard preplant fertilizer additions. Tomato and impatiens bedding plant shoot dry weights increased with up to $5000 \mathrm{mg} \mathrm{N} /$ liter in media containing $10 \%$ kenaf and with up to $3000 \mathrm{mg} \mathrm{N} /$ liter in media containing 30\% kenaf. By selecting the $\mathrm{N}$ concentration of the kenaf soak solution, shoot growth could be matched to that achieved with commercial peat-lites after any post-transplanting period ( 2 to 9 weeks). A further study revealed that kenaf was an effective carrier for Bonzi and Sumagic growth regulators. By combining N-soaked kenaf with growth-regulator-soaked kenaf in the growth medium, bedding plant shoot growth was healthy but restricted.

\section{USE OF PAPER SLUDGES AS SOIL AMENDMENTS IN LAND- SCAPE HORTICULTURE}

Jeffrey Norrie*. Chantal J. Beauchamp, and André Gosselin. Centre for Horticultural Research, Université Laval, Ste-Foy, Québec G1K 7P4, Canada

Residues and by-products resulting from papermaking and recycling are receiving increased attention as beneficial soil amendments. Our research examines de-inked and primary paper sludge as a principal constituent of several substrate mixtures used as soil amendments in landscape horticulture. Three factors will be examined in a strip-split-plot design with four replications: substrate mixture (with organic soil and sand), fertilizer level, and plant species. Several paper sludge-organic soil-sand mixtures (maximum 50\% sludge) were compared to an organic soil-sand control. A $15-\mathrm{cm}$ layer of each mixture was incorporated into existing soil to a depth of $30 \mathrm{~cm}$. Species of Spiraea, Physpcarpus, and Thuja were grown in addition to Kentucky bluegrass (seed and sod) and ryegrass (seed). Growth, rooting, and plant nutrition (foliar analysis) were examined. Preliminary results indicate poor ground cover and $\mathrm{N}$ deficiency in plants grown in all unfertilized plots. For sod and seeded grasses, control plots were slightly more healthy than sludge-amended plots, which was likely due to a greater concentration of available $\mathrm{N}$ from the organic soil. The bush species exibited similar responses. We conclude that a base fertilization is needed to decrease the $\mathrm{C}: \mathrm{N}$ ratio of these substrates to $\approx 20$ to 30 for sustained plant growth regardless of sludge amendments. Toxicity effects were due to the presence of organic contaminants, heavy metals, or both. 


\section{Floriculture \& Ornamental}

\section{IMPACT OF GROWTH CONDITIONS ON POSTHARVEST} QUALITY OF CUT ROSES

Claudine Ménard* and Blanche Dansereau,Département de Phytologie, Centre de Recherche en Horticulture, Pavillon Comtois, Université Laval, Québec G1K 7P4, Canada

The general objective of this project was to study the impact of preharvest growth conditions [supplementary lighting as high-pressure sodium (HPS) or metal halide (MH) lights, and fertilization] on the postharvest quality of greenhouse roses. On 25 Jan. 1991, 288 plants (Rosa $\times$ hybrida 'Royalty', 'After-Glow', and 'Obsession') of 3x caliber were planted in pots. A split-split plot experimental design made up of four blocks was used. Light treatments (three) were main plots while fertilization (two) and cultivars (three cultivars; four plants per cultivar) were subplots and sub-sub-plots, respectively. The two fertilization regimes used had respective $\mathrm{N}: \mathrm{K}$ (in ppm) ratios of 150 $\mathrm{N}: 300 \mathrm{~K}$ (F1) and $300 \mathrm{~N}$ : $300 \mathrm{~K}$ (F2). Three light treatments [ambient light conditions (control) and ambient light conditions + PPF of 100 $\mu \mathrm{mol} \cdot \mathrm{m}^{-2} \cdot \mathrm{s}^{-1}$ supplied by $400-\mathrm{W}$ HPS or MH lamps] were compared. Yields were significantly affected by supplemental light treatments, fertilization, or both regardless of cultivars. Results indicate that stems harvested from HPS and MH light treatments combined with fertilization F1 had a longer vase life than those grown with F2. HPS lamps significantly increased vase life compared to MH. The level of abscisic acid (ABA) was higher under MH than under HPS lamps at time zero $\left(\mathrm{T}_{0}\right)$, and this was similar for all cultivars. Furthermore, when supplemental light was combined with the $\mathrm{F} 1$ fertilization, a lower ABA level was obtained. Low ABA levels were correlated to longer vase life expectancy.

RELATIONSHIPS BETWEEN PREFERENCE TYPES OF EMPLOYEES AND RESPECTIVE JOB CLASSIFICATIONS IN PUBLIC HORTICULTURE

Angela L. Goin. Longwood Graduate Program, 153 Townsend Hall, University of Delaware, Newark, DE 19711

The purpose of this research was to measure relationships between preference types of employees and their respective job classifications in public horticulture. Preference type is the way people prefer to look at the external world, perceive information, make decisions, and live a lifestyle. Improved employee interpersonal relations and productivity, and decreased stress and conflict may result from understanding preference types. The Myers Briggs Type Indicator was used to determine preference types at Longwood Gardens, and at Morris, Scott, and Tyler arboreta. According to this research, a correlation exists between preference types and job classifications. In addition, when job classification preferences were compared to each other, they showed areas of potential conflict and miscommunication. In conclusion, my data generally agree with the general preference type theory.

CALIBRATING TREE GROWTH WITH DIFFERENT STREETTREE PLANTING SPECIFICATIONS: A STUDY OF WASHINGTON, D.C., AREA WILLOW OAKS

Barbara A. Neal* and Thomas Whitlow. Urban Horticulture Institute, Department of Floriculture and Ornamental Horticulture, Cornell University, Ithaca, NY

There is broad consensus that we need a greater understanding of the interaction between trees and urban planting sites. This study was conducted to correlate annual increment growth with different streettree planting specifications, with a primary emphasis on effective rooting volume of soil. The primary site of analysis was Pennsylvania Avenue in Washington, D. C., with four outlying sites chosen for comparison. From a cohort of 450, a randomly generated sample of 60 Pennsylvania Avenue willow oaks was chosen and increment cores taken at diameter breast height. A total of 60 cores was taken from willow oaks at the comparison sites. The annual incremental growth was measured using a microscope equipped with a computerized stage micrometer. The incremental growth per year in the nursery ranged between 6 and $8 \mathrm{~mm}$ and transplant shock generally lasted for 2 to 3 years, until growth regained or exceeded pretransplant levels.

PHOTOSYNTHESIS DURING INUNDATION FOR ACER RUBRUM L. POPULATIONS FROM CONTRASTING HABITATS Louis Anella* and Thomas H. Whitlow, 20 Plant Science, Cornell University, Ithaca, NY 14853

Changes in photosynthesis and root morphology during flooding were studied in container-grown 2- to 3-year-old Acer rubrum L. saplings. The seed was collected from opposite ends of a hydrologic gradient: two upland xeric sites [the George Washington National Forest in Page County, Va. $\left(38^{\circ} 25^{\prime} \mathrm{N}, 78^{\circ} 35^{\prime} \mathrm{W}\right)$, and the Robinson Forest in Perry County, Ky. $\left.\left(37^{\circ} 9^{\prime} \mathrm{N}, 83^{\circ} 7^{\prime} \mathrm{W}\right)\right]$ and a floodplain hydric site [the Presquile National Wildlife Refuge along the James River in Chesterfield County, Va. $\left.\left(37^{\circ} 21^{\prime} \mathrm{N}, 77^{\circ} 16^{\prime} \mathrm{W}\right)\right]$. Each xeric site, containing various half-sib families (maternal parent known, paternal parent from one or more sources), was compared to a different hydric site half-sib family. After 1 week of flooding, the xeric-site trees had lower net photosynthesis than the hydric-site trees and remained significantly lower for the duration of the study. After an initial drop, hydric-site plants showed a recovery in net photosynthesis, indicating a greater ability to acclimate to a flooding stress. Seventy-one percent of the hydric-site plants developed adventitious roots and all retained their leaves. Xeric-site plants did-not develop adventitious roots and $61 \%$ were defoliated after 60 days of continuous flooding. The results indicate ecotypic differentiation in physiological response between Acer rubrum populations collected from opposite ends of a hydrologic gradient.

\section{Cross-commodity}

TRANSPLANTATION OF POTATO SPROUT CUTTINGS ON WET PAPER TO IMPROVE AND INCREASE ROOTING AND SPEED UP MULTIPLICATION BY STEM CUTTING

Andrew Frève*. Station de Recherches, Agriculture Canada, SaintJean-sur-Richelieu, Québec J3B 3E6, Canada; and M. Auger. Ferme Expérimentale, Agriculture Canada, La Pocatière, Québec G0R 1Z0, Canada

Rooting sprout cuttings $(\mathrm{spc})$ is sometimes less successful than stem cuttings (stc). A rooting technique was developed between 1988 and 1991 at La Pocatière. The spc were taken after standing 72 hours in the dark followed by 1 day with 16 hours of light. The spc can be very small $(2 \mathrm{~mm})$ : a node can be split in half if there are two axillary buds face to face. The spc were soaked in IBA and sandwiched between two paper towels. As many as 300 to $400 \mathrm{spc}$ can be placed in a $28 \times 53$ $\mathrm{cm}$ flat. The papers were placed in flats between two transparent covers; the bottom cover contains water. The paper was moistened with water. The cuttings were maintained at $100 \%$ relative humidity for 7 days, then planted in soil in flats. After 5 days on paper, the unrooted cuttings were treated again with IBA on a larger surface and put back in the sandwich. There was less damping-off because the cut part was not placed immediately into the soil. One week after plantation, the plantlets' shape was better and more uniform than those planted directly into soil. The plants rooted on paper produce more stc/ spc and more stc/stc than those rooted in soil.

\section{MULTIPLICATION OF POTATO TUBERS AND MINI-TUBERS} BY SPROUT CUTTING AT 7-DAY INTERVALS

Andrew Frève*. Station de Recherches, Agriculture Canada, SaintJean-sur-Richelieu, Québec J3B 3E6, Canada; and M. Auger, Ferme Expérimentale, Agriculture Canada, La Pocatière, Québec G0R 1Z0, Canada

A multiplication technique by sprout cutting (spc) was developed at La Pocatière from 1988 to 1992. Tubers (t) or mini-tubers (mt) were warmed and, if necessary, treated to break dormancy. After 2 to 4 
weeks of presprouting, they were planted 50 to $100 \mathrm{t}$ per flat $(28 \times 53$ $\mathrm{cm}$ ) half filled with a soil mixture. The $\mathrm{t}$ or $\mathrm{mt}$ were planted partially in soil, leaving the bud end out. They produced roots in 3 to 8 days under 16 hours of light at 22 to $24 \mathrm{C}$. When $50 \%$ of the sprouts have 3 to $4 \mathrm{~cm}$, they were placed in the dark for 3 days and under the initial lighting condition on day 4 . The sprouts were cut on day 5 . The mother plants were maintained in the same conditions for another 72 hours before repeating the cycle 6 to 10 times (with the same $\mathrm{t}$ or $\mathrm{mt}$ ). The multiplication rate depended on tuber size, storage period, and cultivar. The $\mathrm{t}(30 \mathrm{~mm})$ and $\mathrm{mt}(15 \mathrm{~mm})$ of 'Novachip' with 14 and 7 months of storage, respectively, produced 55 and $4.3 \mathrm{spc} / \mathrm{t}$ or $\mathrm{mt}$ in four multiplications over 28 days. The $\mathrm{mt}(12 \mathrm{~mm})$ of 'Tolaas' with 6 months of storage and without breaking dormancy produced $10.3 \mathrm{spc} /$ $\mathrm{mt}$ in eight multiplications over 87 days (it took 4 weeks to grow). An equation considering weeks of storage and t size has been developed with six cultivars and four seedlings to calculate the number of plants multiplied in 1 to 7 weeks.

\section{SPECTRAL CHARACTERISTICS OF CELERY CULTIVARS'} LEAF TISSUES

Nicolas Tremblay* and Yvon Perron. Agriculture and Agri-Food Canada Research Station, 430 Gouin Boulevard, St-Jean-sur-Richelieu, Québec J3B 3E6, Canada

As plant color is often modified by nutrient status, the use of spectoradiometric properties of leaf tissues appears to be a promising tool for quick and inexpensive diagnosis of crop fertility problems. This study was conducted to examine spectral variability associated with celery cultivars. Seedlings of Florida 683, Matador, Utah 5270, and Ventura were grown in a growth chamber for 10 weeks (transplant stage; TS). Reflectance and transmittance measurements were taken on the tallest leaf with a LI-COR LI-1800 spectroradiometer. Remaining seedlings were potted and transferred to a greenhouse for another 8 weeks (mid-growth stage; MS). Transmittance was established as the parameter most suitable to distinguish cultivars. Maximum $F$ ratio was obtained at $\lambda=630 \mathrm{mn}$ at TS, while there were two peeks $(\lambda=470$ and $60 \mathrm{mn}$ ) at MS. A discriminant function was based on $\lambda=470 ; 630$ and $670 \mathrm{mn}$ correctly classified cultivars more than 8 times out of 10 at TS, and more than 7 times out of 10 at MS. Further studies should focus on the induction of nutrient deficiencies and the potential interferences of cultivars with their diagnosis.

GROWTH, CARBON ACQUISITION, AND SOURCE-SINK RELATIONSHIPS IN 'TITAN' RED RASPBERRY

G. Fernandez and M. Pritts. Cornell University, Ithaca, NY 14850

Seasonal changes in growth, photosynthetic rates, temperature, and light response curves of 'Titan' red raspberry (Rubus idaeus L.) were obtained from potted plants grown under field conditions. Primocane dry weight accumulation underwent two phases of linear growth at the beginning and the end of the season, but growth slowed during fruiting. This slower rate of dry weight accumulation also coincided with an increase in root dry weight. Primocane NAR and SLA were highest early in the season. Light response curves differed depending on cane type and time of year. Floricane photosynthetic rates (A) were high during the fruiting period, while primocane A rates remained steady throughout the season. Both primocane and floricane leaflets displayed a midday drop in A rate, with a partial recovery in late afternoon. Photosynthetic rates of both primocane and floricane leaves were very sensitive to high temperatures. Temporal convergence of sink demand from fruit, primocanes, and roots occurs when plants experience high temperatures. This may account for low realized yields in raspberry and the high level of yield component compensation typical of source-limited plants.

USE OF A "LATE WATER" FLOOD FOR PEST CONTROL IN CRANBERRY PRODUCTION: IMPACT ON PEST POPULATIONS, PLANT GROWTH, AND PRODUCTIVITY

Carolyn DeMoranville*. Anne Averill, and Martha Averill, University of Massachusetts Cranberry Experiment Station, East Wareham, MA 02538

In commercial cranberry (Vaccinium macrocarpon Ait.) production, flooding is used as a cultural practice for harvest and for winter protection. In addition, after the withdrawal of the winter flood, cranberry bogs may be reflooded in the spring, a practice known as holding "late water" (LW). This practice was used by early cranberry growers in Massachusetts to avoid spring frost and to promote keeping quality in the harvested fruit. Recently, LW has been "rediscovered" as a cultural tool with the potential for reducing inputs of chemical pesticides and fertilizers. We have begun to document the effects of LW on pest populations and on cranberry plants to provide growers with a solid basis for deciding whether to use this cultural practice. In 1993, 11 LW bogs were studied and compared to control bogs. All of the bogs showed acceptable levels of insect and disease damage on the fruit at harvest. The average number of pesticide applications for the LW bogs vs. controls was 0.9 vs. 2.6 for insecticides and 1.3 vs. 2.8 for fungicides.

ESTABLISHMENT OF THYME (THYMUS VULGARIS L.) BY DIRECT SOWING OR TRANSPLANTING AT TWO DENSITIES Lucette LaFlamme*. Centre for Horticultural Research, Université Laval, Ste-Foy, Québec G1K 7P4, Canada; Marie-Hélène Michaud. Bioplant Research Laboratories, Varennes, Québec, Canada; and Nicholas Tremblay, Agriculture and Agri-Food Canada Research Station, 430 Gouin Boulevard, St-Jean-sur-Richelieu, Québec J3B 3E6, Canada

Cultivation of thyme for medicinal purposes should result in high dry-matter yield and sufficient active principals concentrations. In this experiment two methods of crop establishment were compared: direct sowing (final plant density: 100,000 plants/ha) and planting at two densities: D-1 (100,000 plants/ha) and D-2 (166,000 plants/ha). The use of transplants promoted growth and resulted in yields three times higher than direct sowing (3340 vs. $1002 \mathrm{~kg}$ dry matter/ha). There were significant differences in biomass between the two densities evaluated. Plants under D-1 weighed $33 \mathrm{~g}$ dry matter/plant vs. $22 \mathrm{~g}$ dry matter/plant for D-2. Hence, dry-matter yield per hectare was not affected by planting density. Active principals concentrations were not affected by treatments. So far, it is recommended that cultivation of thyme under Quebec's conditions be based on transplanting at moderate (100,000 plants/ha) density.

\section{WOODY ORNAMENTAL TRIAL NETWORK IN QUEBEC}

C. Richer-Leclerc*, Agriculture Canada, Ferme Expérimentale, 801 Route 344, L'Assomption, Québec J0K 1G0, Canada, and J.A. Rioux. Centre de Recherche en Horticulture, Pavillon de l'Envirotron, University Laval, 2480 Boulevard Hochelaga, Québec G1K 7P4, Canada

The "Reseau d' Essai de Plantes Ligneuses Ornementales du Québec" (REPLOQ) is a research project created in 1982 with a principal mandate to elaborate, develop, and coordinate with specialists on a cooperative research project to evaluate the winter hardiness of ornamental plants throughout the province of Quebec.

COLD HARDINESS OF CORNUS ALBA 'ARGENTEOMARGINATA' AND WEIGELA FLORIDA 'RUMBA' UNDER DIFFERENT FALL FERTILIZER TREATMENTS

Isabelle Duchesne*. Jacques-André Rioux, and Michèle Beaudry. Université Laval, Pavillon de l'Envirotron, Cité Universitaire, SteFoy, Québec G1K 7P4, Canada

Effects of fall fertilization programs on cold hardiness of young Cornus alba 'Argenteo-marginata' and Weigela florida 'Rumba' plants were examined. At the end of Summer 1992, four fertilization programs were applied to 1-year-old woody plants that were propagated in 1991 by cuttings. Fertilization treatments were as follows: 1) discontinuation of liquid fertilizer treatments on 30 Aug., 2) decreasing $\mathrm{N}$ concentration (100 to $0 \mathrm{mg} \cdot$ liter $^{-1}$ of $20 \mathrm{~N}-20 \mathrm{P}-20 \mathrm{~K}$ ) from 15 Aug. to 30 Sept., 3) constant N concentration (100 mg.liter ${ }^{-1}$ of $20 \mathrm{~N}-$ 20P-20K) from 15 Aug. to 30 Sept., and 4) high K concentration (110 $\mathrm{mg} \cdot \mathrm{lite}^{-1}$ of $7 \mathrm{~N}-11 \mathrm{P}-27 \mathrm{~K}$ ) from 15 Aug. to 30 Sept. Whole plants were then removed from pots and roots were cleaned. Plants were then placed under freezing temperatures from 0 to $-20 \mathrm{C}$ at $2 \mathrm{C}$ intervals, with plant samplings done three times during fall-at the end of September, October, and November. After the freezing test, plants were stored at $-2 \mathrm{C}$ and repotted in May 1993 for winter injury evaluation. Preliminary results indicated that the four fertilization programs did not induce a significant effect on cold hardiness of the 
two species. However, it was clear that the degree of cold hardiness was different for each species: Weigela was $\approx 10$ degrees less hardy compared to Cornus in September and October. In November, species demonstrated hardiness at temperatures less than-20C. Cornus also showed cold hardiness at less than $-20 \mathrm{C}$ in October.

\section{Computerization \& Environmental Control}

DETERMINING THE PROFITABILITY OF GREENHOUSE ELECTROTECHNOLOGIES: A MODELING APPROACH

Eric A. Lavoie, Damien de Halleux, André Gosselin, and Jean-Claude Dufour, Department of Agricultural Economics, Université Laval,

Ste-Foy, Québec, Canada

The main objective of this research was to produce a simulated model that permitted the evaluation of operating costs of commercial greenhouse tomato growers with respect to heating methods (hot air, hot water, radiant and heat pumps) and the use of artificial lighting for 1991 and 1992. This research showed that the main factors that negatively influence profitability were energy consumption during cold periods and the price of tomatoes during the summer season. The conventional hot water system consumed less energy than the heat pump system and produced marketable fruit yields similar to those from the heat pump system. The hot water system was generally more profitable in regards to energy consumption and productivity. Moreover, investment costs were less; therefore, this system gives best overall financial savings. As for radiant and hot air systems, their overall financial status falls between that of the hot water system and the heat pump. The radiant system proved to be more energy efficient that the hot air system, but the latter produced a higher marketable fruit yield over the 2-year study.

TIME-RESOLVED IMAGING SPECTROSCOPY OF PLANT ADAPTATIONS TO CHANGES IN THE LIGHT ENVIRONMENT AND APPLICABILITY TO SCREENING MUTANTS

Sylvain L. Dubé*. Centre de Recherche en Horticulture, Pavillon de l'Envirotron, Université Laval, Quebec G1K 7P4, Canada, and John F. Allen. Plant Cell Biology, University of Lund, Box 7007, S-220 07 Lund, Sweden

Photosynthesis, a major determinant in growth and survival of plants, is very sensitive to the energy balance of the processes triggered by the physico-chemical environment. It is, therefore, an excellent indicator of the plants' physiological state. Fundamental events in photosynthesis can be studied non-invasively and non-destructively by examining there-emission of absorbed light energy as chlorophyll a fluorescence. In this study we present digitized consecutive images of fluorescence of intact leaves of Arabidopsis sp. The relative intensity and kinetics of fluorescence of several AOI (areas of interests) of each image have been analyzed and compared. We demonstrate the feasibility of this technique for studying the physiology of light adaptations (state-transitions) of several organisms simultaneously and its applicability in indentifying mutants. Implications of this technique to the horticulture industry will be discussed.

A FRAMEWORK FOR COMPUTERIZED FARM DECISION-SUPPORT SYSTEMS

Laurent Gauthier* and Thierry Néel, Département de Génie Rural, Centre de Recherche en Horticulture, FSAA, Université Laval, Quebec G1K 7P4, Canada

A software system (SAGE) was built for on-farm decision support. The objective was to provide a framework for constructing and deploying knowledge-based decision support in the areas of integrated pest management, fertilization, and field operations. The framework is open by design and includes a generic model of an agro-ecosystem as well as various mechanisms allowing for the continued growth in scope and function of the software. The SAGE system is designed to provide a number of building blocks and predefined decision-support strategies that can be adapted to specific needs and situations. It operates on a personal computer and is based on the use of an objectoriented technology for software construction and operation. A prototype of the system has been built and is being used to build commodityspecific decision-support modules.

\section{Transgenic \& Plant Metabolism}

COMPARISON OF NEAR-INFRARED REFLECTANCE SPECTROSCOPY AND WET CHEMICAL ANALYSIS ON THATCH COMPOSITION

Andree-Anne Couillard*, A.J. Turgeon, J.S. Shenk, and M.O. Westerhaus. Agronomy Department, The Pennsylvania State University, University Park, PA 16802

The ability to predict thatch composition with the use of nearinfrared reflectance spectroscopy (NIRS) was investigated. This study compared a new quick test for evaluating different thatch components using NIRS with the Van Soest wet chemical analysis. Creeping bentgrass (Agrostis palustris Huds.) thatch samples were taken from an experimental golf green at the Valentine Turfgrass Research Center at Penn State Univ. Fresh and dried ground samples were scanned from 400 to $2500 \mathrm{~nm}$ with a near-infrared monochromator. Dried ground samples were analyzed in four replicates using the Van Soest procedures for the acid detergent fiber, cellulose, and lignin. Moisture and organic matter contents were also evaluated in the laboratory. Preliminary comparisons between predicted NIRS values and laboratory results were encouraging. NIRS analysis of thatch could become a convenient, rapid, and inexpensive alternative to wet chemical analysis for thatch assessment.

POTENTIAL OF PROTEINASE INHIBITORS FOR THE PRODUCTION OF TRANSGENIC PLANTS TOLERANT TO INSECT PESTS. I. FUNCTIONAL ASPECTS

Dominique Michaud*. Serge Overney, Binh Nguyen-Quoc, and Serge Yelle. Centre de Recherche en Horticulture, Pavillon de l'Envirotron, Université Laval, Québec G1K 7P4, Canada

In the past few years, transformation of plant genomes with proteinase inhibitor (PI) genes has been proposed as an effective way to produce insect-tolerant plants. For such a control approach, however, biochemical studies are necessary to assess the effect of PIs on not only insect digestive proteinases (target enzymes) but also plant endogenous proteinases (nontarget enzymes). As an example, transformation of potato (Solanum tuberosum L.) with oryzacystatin (OC) genes, two cysteine PIs, was considered for controlling Colorado potato beetle (CPB; Leptinotarsa decemlineata Say). The use of electrophoretic approaches and standard assays showed that CPB uses at least 14 cysteine proteinases for protein digestion throughout its development. Proteinases of the same class were also detected in sprouting potato tuber extracts, suggesting a potential interference of CPIs in transgenic plants. While OCs inhibit a significant fraction of CPB digestive proteinases, no inactivation of potato proteinases was detected. This apparent absence of direct interference suggests the real potential of OCs for producing CPB-tolerant transgenic potato plants.

POTENTIAL OF PROTEINASE INHIBITORS FOR THE PRODUCTION OF TRANSGENIC PLANTS TOLERANT TO INSECT PESTS. II. POTENTIAL LIMITATIONS

Serge Overney*. Dominique Michaud. Binh Nguyen-Quoc. and Serge Yelle. Centre de Recherche en Horticulture, Pavillon de l'Envirotron, Université Laval, Québec G1K 7P4, Canada

In recent years, several studies have demonstrated the potential of proteinase inhibitors (PIs) for controlling insect pests. Used as a component of an integrated pest management program, such an approach must, however, be considered with care, given the potential risks of interference on other control approaches. In particular, the effect of PIs on digestive proteinases of beneficial insects must be 
determined. As an example, this study analyzed the effect of oryzacystatins (OCs), two cysteine PIs isolated from rice, on digestive proteinases of Perillus bioculatus, a predator of the Colorado potato beetle (CPB; Leptinotarsa decemlineata Say), a major pest. Electrophoretic analyses showed the existence of several cysteine proteinase forms in the digestive tract of $P$. bioculatus. For each developmental stage, OCs dramatically inhibited proteolytic activity, showing an affinity between these inhibitors and the digestive proteinases of the predator. Despite their potential for controlling CPB, the two rice cystatins thus represent possible growth-suppressing compounds for the beneficial insect $P$. bioculatus. Work is currently under way to assess the compatibility of the two control approaches.

EFFECTS OF CONTINUOUS LIGHTING ON ENZYME ACTIVITIES OF LEAF CARBON METABOLISM OF TOMATO AND PEPPER PLANTS

Dominique-André Demers*. Serge Yelle, and André Gosselin, Centre de Recherche en Horticulture, Département de Phytologie, Université Laval, Québec G1K 7P4, Canada

Exposure of tomato and pepper plants to long photoperiods (20 hours or more for tomato; 24 hours for pepper) results in leaf chlorosis (tomato), leaf deformities (pepper), and decreased growth and productivity (both species). Some researchers have suggested that excessive starch accumulation in the leaves could be the cause of the negative effects. We observed that tomato and pepper plants do accumulate more starch in their leaves when grown under a long photoperiod (24 hours) compared to a shorter one (16 hours). However, our results indicated that these accumulations were not caused by a limited sink strength but by an alteration of the carbon metabolism at the leaf level. In our last experiment, we studied the activity of enzymes [sucrose phosphate synthase (SPS), sucrose synthase (SS), invertase] of leaf carbon metabolism in tomato and pepper plants grown under different photoperiods (natural, natural + supplemental light of $100 \mu \mathrm{mol} \cdot \mathrm{m}^{-2} \cdot \mathrm{s}^{-1}$ during 16 and 24 hours). We observed a $10 \%$ to $15 \%$ decrease in leaf SPS activity in tomato (not in pepper) plants grown under a 24-hour photoperiod. In both species, invertase and SS activities were not affected by photoperiod treatments. In tomato plants grown under a 24-hour photoperiod, the decrease in SPS activity corresponded to the appearance of leaf chlorosis (6 to 7 weeks after the beginning of treatments). Therefore, it appears that leaf carbon metabolism could be involved in the development of negative effects of long photoperiod in tomato plants, but not in pepper plants. The fact that photoperiod had no apparent effect on leaf carbon metabolism of pepper may explain why this species can tolerate longer photoperiods than tomato plants.

\section{Posters}

EFFECTS OF SUCROSE ON METABOLIZE POOL SIZES AND RIBULOSE-1,5-BISPHOSPHATE CARBOXYLASE/OXYGENASE ACTIVITY IN STRAWBERRY PLANTLETS CULTIVATED IN VITRO

Chafik Hdider* and Yves Desjardins, Département de Phytologie, Centre de Recherche en Horticulture, Faculté des Sciences de l'Agriculture et de l'Alimentation, Université Laval, Québec G1K 7P4, Canada

To identify the physiological and biochemical events leading to the negative effects of sucrose in culture medium on the photosynthetic capacity of plantlets cultivated in vitro, time-course changes in photosynthesis, metabolize pool sizes, and ribulose-1,5-bisphosphate carboxylase/oxygenase (Rubisco) activity were investigated in strawberry (Fragaria $\times$ ananassa Duch. CV. Kent) plantlets following their transfer to medium with or without sucrose. When the plantlets grown in medium without sucrose were transferred to a similar medium with $30 \mathrm{~g}$ sucrose/liter, their net photosynthesis decreased and their level of phosphorylated compounds increased with time. In addition, initial $\mathrm{K}_{\text {cat }}$, total $\mathrm{K}_{\mathrm{cat}}$, and the activation state of Rubisco decreased in these plantlets. Conversely, when the plantlets grown in medium with $30 \mathrm{~g}$ sucrose/liter were transferred to a similar medium without sucrose, their net photosynthesis slowly increased with time and their level of phosphorylated compounds slowly decreased. A slow increase with time of initial $\mathrm{K}_{\mathrm{cat}}$, total $\mathrm{K}_{\mathrm{cat}}$, and the activation state of Rubisco was also observed in these plantlets. The results of the present research suggest that the reduced photosynthetic capacity of strawberry plantlets cultivated in vitro in the presence of sucrose was the consequence of reduced Rubisco efficiency due to its deactivation and the possible presence of a putative tight binding inhibitor.

COMPARISON OF SENSORY, CHEMICAL, AND COLOR ATTRIBUTES OF DISEASE-RESISTANT APPLE CULTIVARS J.R. Schupp*, T.M. Work, R.J. Bushway, L.B. Perkins. and A.A. Bushway, University of Maine, Highmoor Farm, Monmouth, ME 04259-0179

In 1989 and 1990, the sensory preference, chemical, and color attributes of three disease-resistant apple cultivars, 'Liberty', 'Nova Easygro', and 'Jonafree', were compared to 'McIntosh' at harvest and following 3 months of storage at $2 \mathrm{C}$. Throughout the testing period, panelists equally preferred the flavor of 'Liberty' and 'McIntosh'. 'Liberty' was significantly preferred for texture during the four sampling periods. 'Jonafree' was significantly less preferred when compared to 'McIntosh'. The color of 'McIntosh' was preferred overall, followed by 'Liberty'. 'Jonafree' was least preferred for color. The percent soluble solids, titratable acidity, fructose, and sucrose concentrations decreased over time. Glucose and the sugar : acid ratio increased with time. Significant differences in chemical and color evaluations were found from year to year.

\section{BREADFRUIT SHELF-LIFE EXTENSION BY CACL $_{2}$ TREAT-} MENT

Jeanne Bernardin*1. Clement K. Sankat ${ }^{2}$, and Claude Willemot ${ }^{1}$, ${ }^{1}$ Food Science and Technology Department, Université Laval, Québec G1K 7P4, Canada; ${ }^{2}$ Agricultural Engineering Department, University of the West Indies, St. Augustine, Trinidad

The effect of Ca on breadfruit (Artocarpus altilis) postharvest storage was investigated. Mature-green breadfruits were hand-harvested in Blanchisseuse, Trinidad, dipped in $0 \%, 2 \%, 5 \%$, and $10 \%$ $\mathrm{CaCl}_{2}-2 \mathrm{H}_{2} \mathrm{O}$ solutions for $0.5,1.0,3.0,6.0$, and 12.0 hours, and stored at $16 \mathrm{C}$ for 9 days. Calcium content was shown to increase in both peel and pulp with increasing concentration and length of treatment. The $5 \%$ and $10 \% \mathrm{Ca}$ treatment had a detrimental effect on color and texture as determined by sensory evaluation. The $2 \%$ treatment delayed fruit softening, particularly for 3-, 6-, and 12-hour dips. At the end of storage, total soluble solids content was affected little by the treatments, while pectin solubilization was delayed. Breadfruit shelf life was extended from 4 to 9 days with $2 \%$ treatments. Peel browning remains the limiting factor for storage.

HYSTERESIS OF SOIL-ROOT INTERFACE WATER POTENTIAL AND TRANSPIRATION IN RESPONSE TO SOIL DEHYDRATION FOR PRUNUS $\times$ CISTENA GROWN IN DIFFERENT SOIL MIXES

Hui-lian Xu*. Jean Caron. and André Gosselin. Centre de Recherche en Horticulture, Université Laval, Ste-Foy, Québec G1K 7P4, Canada

Water potential at soil-root interface $\left(\psi_{s . r}\right)$ indicates soil water availability to the plants. It is related to plant water potential and transpiration. To know the characteristics of $\psi_{\text {sir }}$, in the plants under a subirrigation system, hysteresis of $\psi_{\omega}$, as well as xylem water potential $\left(\psi_{x}\right)$ and transpiration were examined in response to soil dehydration for Prunus $\times$ cistena grown in three soil mixes: mix 1-composted bark, peat, and sand; mix 2 - peat, bark, sand, and compost; and mix 3 - peat, sawdust, and sand. When the soil mixes were dried from high to low water potential $\left(\psi_{s}\right)$, plants grown in mix 2 maintained higher $\psi_{\text {s }}$, as well as higher $\psi_{\mathrm{x}}$ and higher transpiration. However, when the soil mixes were dehydrated from the bottom, the relationships of $\psi_{s i r}$, $\psi_{\text {v }}$, and transpiration to $\psi_{\text {s }}$ showed strong hysteresis effect. $\psi_{\text {s.t }}$ was always lower at a given $\psi_{s}$ when soil was rewetted from dry to wet conditions than when soil was dried from wet conditions. $\psi_{x}$ and transpiration also showed hysteresis in response to soil dehydration. The extent of hysteresis was the largest in mix 2 and the smallest in mix 
3. Hysteresis of $\psi_{\mathrm{x}}$ or transpiration showed a similar trend to that of $\psi_{\text {s.r. }}$. This suggests that $\psi_{\text {s.t }}$ is a good indicator of soil water availability to the plants and more directly related to $\psi_{\mathrm{X}}$ and transpiration than is $\psi_{s}$. The difference in hysteresis of $\psi_{\text {s. }}$ among soil mixes might be related to the properties of hydraulic conductance, which are determined by the soil texture. Hence, further study is needed to elucidate the mechanism of the hysteresis phenomenon.

\section{QUEBEC SMALL-FRUIT RESEARCH AND DEVELOPMENT-} A NEW APPROACH WITH THE GARD-PF

Serge Bégin, Alain Garneau, Michèle Roy, and Pierre O. Thibodeau*, Agriculture Québec, Direction de la Recherche et du Développement, 2700 Einstein, Ste-Foy, Québec G1P 3W8, Canada

Consequent to the propositions of the Québec Agriculture Summit concerning suggestions to increase research efforts and technological transfer and market awareness, members of the research division of the provincial ministry of agriculture have established an animation team in small-fruit research and development. This group will be composed of scientists whose mandate will be to lead and rally the small-fruit sector into regrouping, to provide adequate tools necessary for research and development (bibliography, periodicals, etc.), to counsel and plan research and development projects, and to give advice on actions and means of development in a particular sector.

\section{PLASTICULTURE RESEARCH AND DEVELOPMENT IN QUE- BEC REGION}

Serge Bégin*, Agriculture Québec, Direction de la Recherche et du Développement, 2700 Einstein, Ste-Foy, Québec G1P 3W8, Canada; Joe Calandriello, Poly Expert, 850 Boulevard Munck, Laval, Québec H7S 1B1, Canada; and Pierre A. Dubé, Département de Phytologie, Université Laval, Ste-Foy, G1K 7P4, Canada

In Québec the intensive use of plastic films in field production of vegetables and fruit is evident by increased acreage for this sector of agriculture since 1985 . This technique is used particularly for sweet corn, cucurbitaceae and solanaceae, and strawberry production. Since 1987 some research projects have been established by the research and development division of the Quebec ministry of agriculture (MAPAQ) to adapt this technology to the Québec climate and to the needs of producers. The objectives of MAPAQ researchers are to extend the production season, improve the quality and productivity of fruit and vegetable crops, diminish production costs, and propose profitable alternatives for controlling crop pests.

\section{EFFECT OF SPECTRAL QUALITIES OF PLASTIC MULCH ON} WEED DEVELOPMENT AND GROWTH

Fahrurrozi Aziz* and Katrine A. Stewart. Department of Plant Sciences, Macdonald Campus, McGill University, 21,111 Lakeshore Road, Ste Anne de Bellevue, Québec H9X 3V9, Canada

The types of plastic mulch used in horticultural production often fulfill only a few of the grower's needs. Black plastic mulch controls weeds, but can burn young plants. Clear mulch, while warming the soil and enhancing early crop growth, allows prolific weed growth and development. Accordingly, an experiment using a randomized complete-block design with-four replications was set up to compare the effects of black, microperforated black, silver, and wavelength-selective (IRT-76) green mulches, and bare soil on weed growth and development, and on soil temperature and moisture. Each mulch was evaluated for its optical properties. All mulches significantly reduced final stands of seeded weeds compared with bare soil. IRT-76 green had the warmest mean soil temperatures, followed by silver, black, and microperforated black mulches, and bare soil. Soil moisture content was generally higher under plastic mulches than bare soil.

INFLUENCE OF NITROGEN, POTASSIUM, AND MAGNESIUM FERTILIZATION ON DAY-NEUTRAL STRAWBERRIES IN QUEBEC

M. Lamarre*. Ferme Expérimentale, Agriculture Canada, L'Assomption, Québec J0K 1G0, Canada; and M.J. Lareau, Station de Recherche, Agriculture Canada, 430 Boulevard Gouin, St-Jean-surRichelieu, Québec J3B 6Z8, Canada

From June to Sept. 1993, the day-neutral strawberry cultivar Tribute was subjected to two $\mathrm{N}$ fertilization rates $(50$ and $100 \mathrm{~kg} / \mathrm{ha}$ ), four $\mathrm{K}$ fertilization rates $(0,60,120$, and $180 \mathrm{~kg} / \mathrm{ha})$, and three $\mathrm{Mg}$ fertilization rates $(0,25$, and $50 \mathrm{~kg} / \mathrm{ha})$ through trickle irrigation. The $\mathrm{N}$ and $\mathrm{K}$ treatments had no significant influence on yield and fruit size. The Mg treatments increased fruit size and did not affect yield.

THE EFFECTS OF TUFTED APPLE BUDMOTH INJURY OR REDUCED FUNGICIDE PROGRAMS ON THE STORABILITY OF APPLES

C.L. Barden*, G.M. Greene, L.A. Hull, and K.D. Hickey, Departments of Horticulture, Entomology, and Plant Pathology, Fruit Research Laboratory, The Pennsylvania State University, P.O. Box 309, Biglerville, PA 17307

Tufted apple bud moth (TABM) damage had little or no effect on the soluble solids, starch, or firmness of stored apples. Decay increased from $0 \%$ to $18 \%$ in 'Golden Delicious' and from $2 \%$ to $6 \%$ in 'Delicious' between control fruit and those with the most TABM damage (> $10 \mathrm{~mm}$ aggregate diameter, significant linear relationships $R^{2}=0.41$ and 0.12 , respectively). Weight loss increased 2- to 3-fold in apples in the highest damage category. These results show that the post-storage quality of apples with slight TABM damage $(<5 \mathrm{~mm}$ aggregate diameter) does not decline more rapidly than undamaged fruit. The best controlled atmospheres for storing undamaged fruit were also the best for storing damaged fruit. Widely varying fungicide spray programs did not influence the quality or decay levels of apples following storage. However, even those fruit from blocks with few or no sprays had very little decay due either to low inoculum or unfavorable environmental conditions.

\section{SOMATIC EMBRYOGENESIS OF MUSSAENDA 'QUEEN} SIRIKIT'

Christopher S. Cramer and Mark P. Bridgen. Department of Plant Science, University of Connecticut, 1376 Storrs Road U-67, Storrs, CT 06269

Disinfected midrib sections of Mussaenda 'Queen Sirikit' $\approx 3$ to 4 $\mathrm{mm}$ in size were cultured on a basal medium of Murashige and Skoog salts and vitamins, $87.7 \mathrm{~mm}$ sucrose, and $5 \mathrm{~g}$ Sigma agar/liter supplemented with several concentrations of indole-3-acetic acid (IAA) ( 0 , 5.0, 10.0, 20.0 $\mu \mathrm{M})$ and 6-benzylaminopurine (BAP) $(0,0.5,1.0,2.5$, $5.0,10.0,25.0,50.0 \mu \mathrm{M})$. Cultures were subculture onto the same treatment after 5 weeks and observed weekly for 15 weeks for the presence of somatic embryos. As somatic embryos were produced, they were subculture onto basal medium supplemented with $0.5,1.0$, 2.5 , or $25.0 \mu \mathrm{M}$ BAP. Callus was first observed at 2 weeks in cultures grown on basal medium supplemented with 5.0-20.0 $\mu$ m IAA and 0$50.0 \mu \mathrm{M}$ BAP. Somatic embryos were observed at 8 weeks on basal medium supplemented with 5.0-10.0 $\mu \mathrm{M}$ IAA and 2.5-5.0 $\mu \mathrm{M}$ BAP. Callus cultured on 0-10 $\mu \mathrm{M}$ IAA and 5.0-10.0 $\mu \mathrm{M}$ BAP produced the greatest number of somatic embryos by 15 weeks. Somatic embryos subculture to basal medium supplemented with $25.0 \mu \mathrm{M}$ BAP proliferated shoots, while eliminating BAP from the medium resulted in root and callus production. Shoots and entire plants were removed from in vitro conditions and successful] y acclimated to greenhouse conditions. Somatic embryo-derived plants flowered sporadically 25 to 35 weeks after removal from in vitro conditions. Variations in sepal number and leaf number per node were observed at $1 \%$ to $5 \%$.

\section{ELECTROPORATION-MEDIATED GENE TRANSFER TO PRO-} TOPLASTS OF ASPARAGUS OFFICINALIS L.

Sandip Mukhopadhyay* and Yves Desjardins, Centre de Recherche en Horticulture, FSAA, Pavillon de l' Envirotron, Université Laval, Quebec G1K 7P4, Canada

Transient expression of electroporation-mediated DNA uptake was monitored in callus-derived protoplasts of two asparagus ( $A s$ paragus offcinalis L.) genotypes by measuring the GUS activity. The level of expression and the viability of the protoplasts were influenced by the voltage and duration of the electric pulse. An increased plasmid DNA concentration and the presence of polyethylene glycol (PEG) in the electroporation medium enhanced the transient expression level. A considerable increase in GUS activity was observed in the presence of both PEG and heat-shock treatments than with PEG treatment alone. An optimal level of GUS activity was obtained after electroporation with a capacitive discharge of $500 \mathrm{~V} / \mathrm{cm}$ and $94 \mathrm{~ms}$ duration. The two 
genotypes differed in their responses in vitro and also showed variable levels of transient expression. The present technique was suitable to obtain transgenic plants, as histochemical GUS assay revealed GUS activity in the protoplast-derived microcolonies as well as in callus tissues.

\section{COLD HARDINESS OF SIX WOODY PLANTS}

Isabelle Duchesne and Jacques-André Rioux. Université Laval, Pavillon de l'Envirotron, Cité Universitaire, Ste-Foy, Québec G1K 7P4, Canada

To examine injuries caused by freezing temperature, six woody plants were placed under temperatures ranging from 0 to $20 \mathrm{C}$. Control plants were placed at 0 or $-2 \mathrm{C}$, depending on the field sampling period. Freezing tests were done three times (September, October, and November) during the fall. In 1992, six species were tested: Genista tinctoria 'Lydia', Parthenocissus 'Veitchii', Weigela $\times$ florida 'Variegata', Spiraea japonica 'Shirobana', Spiraea japonica 'Coccinea', and Arctostaphylos uva-ursi. After testing, all plants were stored at $-2 \mathrm{C}$ for the remainder of the winter. The following May, plants were repotted into containers. Effects of freezing temperatures on plant growth were recorded at the end of the following summer. Preliminary results indicate that the most sensitive species to cold temperatures were Parthenocissus 'Veitchii' and Arctostaphylos uvaursi. Plants of these two species did not survive the summer. However, for the third sampling period, Parthenocissus 'Veitchii' (-18C) had better cold hardiness than A. uva-ursi (-9.5C). Genista tinctoria 'Lydia' appeared to have the same cold hardiness $(-10 \mathrm{C})$ for the three sampling periods. The last three species had shown increasing cold hardiness beginning at around $-8 \mathrm{C}$ in September to about $-18 \mathrm{C}$ in November.

\section{EFFECT OF NUTRIENT SOURCE ON THE GROWTH OF PHYSOCARPUS OPULIFOLIUS 'NANUS', WEIGELA FLORIDA 'RUMBA', AND SPIRAEA × BUMALDA 'GOLDFLAME'}

Isabelle Duchesne, Jacques-André Rioux, and André Gosselin, Université Laval, Pavillon de l'Envirotron, Cité Universitaire, SteFoy, Québec G1K 7P4, Canada

Six fertilization programs were applied to three woody plants: Physocarpus opulifolius 'Nanus', Spiraea $\times$ bumalda 'Gold flame', and Weigela florida 'Rumba'. The objective of this study was to determine fertilization programs best adapted to container woodyplant production. Treatments were: 1$)$ Nutricote $(5 \mathrm{~g} /$ liter of growth medium) + weekly fertigation of 20N-20P-20K (300 mg N/liter); 2) Coïc-LeSaint solution for each irrigation; 3) Nutricote + weekly fertigation of liquid 9N-9P-9K (300 mg N/liter); 4) fertigation with complete nutrient solution (125 mg N/liter); 5) Polyon + weekly fertigation of $20 \mathrm{~N}-20 \mathrm{P}-20 \mathrm{~K}$ ( $300 \mathrm{mg} \mathrm{N} / \mathrm{liter}$ ); and 6) Nutralene + weekly fertigation of 20N-20P-20K (300 mg N/liter). The experiment took place between 25 June 1991 and 15 Aug. 1992. Results show that, independent of species, plants given fertilization program 4 had lower plant height $(57 \mathrm{~cm})$ and stem dry weight $(97 \mathrm{~g})$ than plants under other treatments, the average for each parameter being $72 \mathrm{~cm}$ and $127 \mathrm{~g}$, respectively. Plant height was highest in Physocarpus with treatment programs 2, 4, 5, and 6. Weigela had greater growth under program 2, while Spiraea had more growth with programs 1, 3, and 6. Consequently, differences exist between optimum fertilization programs used for each species studied.

TRANSLATABLE mRNA IN THE PERICARP OF TOMATO CULTIVARS DIFFERING IN CHILLING TOLERANCE

Han-Ling YU ${ }^{1 *}$, Claude Willemot ${ }^{\perp}$, Paul Nadeau ${ }^{2}$, Serge Yelle ${ }^{\perp}$, and Yves Castonguay ${ }^{2}{ }^{1}$ Plant Science Department, Université Laval, Québec G1K 7P4, Canada; ${ }^{2}$ Research Station, Agriculture Canada, 2560 Boulevard Hochelaga, Ste-Foy, Québec G1V 2J3, Canada

Translatable mRNAs from two tomato (Lycopersicon esculentum Mill.) cultivars differing in chilling tolerance were compared after 16 days of chilling at $4 \mathrm{C}$ and after return to $20 \mathrm{C}$ for 1 and 5 days. Before chilling, the translation products, resolved by 2D NEPHGE, showed significant differences between more tolerant 'New York 280' (NY) and less tolerant 'Early Cherry' (EC). In NY, chilling reduced the level of five to 10 mRNAs and enhanced or induced that of several other mRNAs. After transfer to $20 \mathrm{C}$, the trend was progressively reversed. Changes in the levels of two low-molecular-weight basic peptides were most noticeable. One, absent in NY before chilling, was strongly expressed after chilling and $24 \mathrm{~h}$ after transfer to 20C, but disappeared 5 days after transfer. The level of this peptide increased slightly in EC at low temperature and was maintained after transfer to $20 \mathrm{C}$. The level of the other, high in NY before chilling, was sharply reduced after chilling. In contrast, the level of this polypeptide was low in EC under all treatments.

FIELD PERFORMANCE AND SENSORY ANALYSIS OF EARLY TO MIDSEASON TOMATO CULTIVARS

D. Handley*, M. Schupp, T. Work, R. Work, and A. Bushway, University of Maine, P.O. Box 179, Monmouth, ME 04259

Twelve early to midseason ripening tomato cultivars were evaluated for early and total marketable yield, fruit size, and external characteristics under the cool, short growing season of northern New England. The acceptability of external and internal color, texture, and flavor of four cultivars was evaluated by a sensory panel of 50 members. There was little difference between cultivars in total yield. This was probably due to an early frost that destroyed much of the later ripening fruit. 'Summerset' had the highest early and overall yields but the smallest fruit size. 'Johnny's 361 ' had high overall yield and large fruit with good early yields. 'Pilgrim' had high early yield, good overall yield, and fair fruit size. 'Jetstar' and 'Daybreak' fell into the middle of the range for total yield and fruit size, but 'Jetstar' had very low early yield. 'Pik Red' and 'Pik Rite' had low early and total yields but good fruit size. 'Moreton Hybrid' had fair early and total yields and small fruit size. In the sensory analysis, 'Sunrise' had the highest rated external color, while 'Moreton Hybrid' had the lowest rating. Internal color ratings did not vary greatly, although 'Sunrise' was least acceptable in this characteristic. 'Jetstar' was rated highest for flavor and texture, followed by 'Moreton Hybrid', 'Sunrise', and 'Valley Girl'.

\section{EFFECT OF VAPOR PRESSURE DEFICITS ON TRANSPIRA-} TION OF GREENHOUSE TOMATO PLANTS

Laurent Gauthier, Maher Trigui*, André Boisvert, and Mohamed Benmoussa, Département de Génie Rural, Centre de Recherche en Horticulture, FSAA, Université Laval, Québec G1K 7P4, Canada

Transpiration is essential to the performance of tomato plants. In greenhouses, transpiration can be impeded by low vapor-pressure deficits (VPD). An experiment was conducted to measure the effect of VPD on transpiration rates for greenhouse tomatoes grown on a nutrient film. Four treatments were applied: high ( $0.8 \mathrm{kpa})$ day and night VPDs; high day and low night $(0.4 \mathrm{kPa})$ VPDs; low day and low night VPDs; and variable VPDs. The VPD was controlled using fogging and ventilation. Hourly transpiration values were recorded. Results show a significant difference between treatments. The measured transpiration rates were compared to the values calculated with a transpiration model. A good fit between measured and calculated values was observed. The model is being used within a dynamic VPD control strategy.

EFFECTS OF FERTIGATION MANAGEMENT ON WATER RELATIONS OF TOMATO PLANTS GROWN IN PEAT, ROCKWOOL, AND NFT

Hui-lian $\mathrm{Xu}^{*}$, Laurent Gauthier, and André Gosselin, Centre de Recherche en Horticulture, Université Laval, Ste-Foy, Québec G1K 7P4, Canada

Tomato plants (Lycopersicon esculentum Mill. cv. Capello) were grown in peat bags, rockwool slabs, and NFT in a greenhouse to examine the effects of nutrient solution electrical conductivity (EC) and potential evapotranspiration (PET)-dependent EC variation on plant water relations. Peat bags were irrigated by a PET-dependent irrigation system. EC was varied from 1 to $4 \mathrm{mS} \cdot \mathrm{cm}^{-1}$ according to PET under -5 and $-9 \mathrm{kPa}$ of substrate water potential setpoints (SWPS). The plants in rockwool and NFT were treated with ECs of 2.5, 4, and $5.5 \mathrm{mS} \cdot \mathrm{cm}^{-1}$. Peat bags and rockwool slabs were overwatered once a week to wash out the accumulated salts. Leaf water potential $\left(\psi_{1}\right)$ and relative water content $(\theta)$ were measured before and after plants were overwatered. Turgor $(P)$ and osmotic $(\pi)$ potentials were estimated from the pressure-volume method. Before plants were overwatered, $\psi_{1}$ was significantly lower in the plants with high EC and low SWPS treatments and also lower in variable EC-treated plants, but $P$ main- 
tained close to the control value. After plants were overwatered, $\psi_{1}$ recovered close to the control level and $P$ became higher because of the lower $\pi$ in the treatments of high EC, variable EC, and/or low SWPS. At a given $\psi_{1}$, the plants with high EC, variable EC, and/or low SWPS maintained higher $\theta$. The analysis of the pressure-volume curve showed that the leaves treated with high EC, variable EC, and/or low SWPS had higher turgid water content, higher symplasmic (osmotically active) water content, lower apoplasmic (osmotically inactive) water content, and lower $\theta$ point of zero turgor (incipient plasmolysis). Maintenance of $P$ after overwatering was directly proportional to photosynthetic capacity. We suggest that osmotic adjustment occurs in response to high EC, low SWPS, or both and that overwatering substrates and varying EC can not only avoid salinity stress, but also improve turgor maintenance.

CLASSIFICATION OF SWEET PEA CULTIVARS BY MEANS OF DISCRIMINANT ANALYSIS

Nicolas Tremblay*, Agriculture and Agri-Food Canada Research Station, 430 Gouin Boulevard, St-Jean-sur-Richelieu, Québec J3B 3E6, Canada

Processing plants requires that cultivars be categorized as either small, medium, or large peas to meet the different markets. A reliable nutrient diagnosis system based on sweet pea leaf analysis should be robust to the type of cultivar. The objective of this study was to determine whether the type of cultivar should be taken into account in producing the nutrient diagnosis. Proportions of peas in categories 1 (small) to 5 (large) were determined for 18 cultivars produced under commercial conditions over 3 years. Cluster analysis was conducted with the constraint of revealing three groups, as homogeneous as possible with regard to their proportions in the different categories. Three cultivars were identified as belonging to the small, nine to the medium, and six to the large group. The archetype of each group was characterized. The function discriminated among the cultivars perfectly along the canonical axes. However, no classification was possible when the nutrient composition variables $(\mathrm{N}, \mathrm{P}, \mathrm{K}, \mathrm{Ca}, \mathrm{Mg}, \mathrm{B}$, $\mathrm{Fe}, \mathrm{Mn}, \mathrm{Zn})$ were used for discriminating cultivars' types. Hence, sweet pea cultivars of different types do not differ substantially in leaf composition.

\section{DETECTION OF BACTERIAL RING ROT OF POTATO USING DNA PROBE AND PCR}

R. Hogue*, S. Roy, C. Bernard, and L. Laverdière, Agriculture Québec, Service de Phytotechnie de Québec, 2700 Einstein, Ste-Foy, Québec G1P 3W8, Canada

One hundred twenty-eight field samples of 25 potato stem sections were analyzed for detecting bacterial ring rot (BRR). Samples containing more than $10^{5}$, between $10^{5}$ and $10^{4}$, and $<10^{4}$ immunofluorescing BRR cells per milliliter of sample, detected using immunofluorescence-antibody staining with MAb9A1, were used to compare the efficiency of two other detection methods. Samples were screened with a digoxigenin-labeled DNA probe (Bh1 2, $0.6 \mathrm{kbp})$ detected by chemioluminescence on nylon membrane. Samples also were screened with a PCR test using primers derived from the sequence of the Bh12 probe. DNA probe tests on these three bacterial concentrations showed a detection efficiency of $100 \%, 76.8 \%$, and $8.0 \%$, respectively, whereas detection efficiencies of $100 \%, 100 \%$, and $84.5 \%$ were obtained with PCR tests. Almost all positive samples gave the expected 403 bases ethidium-bromide-stained band when the amplified products were analyzed on $1.4 \%$ agarose gel. Thus, the PCR test was a sensitive detection method for screening bacterial ring rot of potato.

\section{SELECTING PREDATORS FOR BIOLOGICAL CONTROL OF TOMATO RUSSET MITE}

Jacques Brodeur*. M'hammed Bouaicha, and André Bouchard. Département de Phytologie, Centre de Recherche en Horticulture, Pavillon Paul-Comtois, Université Laval, Québec G1K 7P4, Canada

In recent years, the tomato russet mite (TRM) [Aculops lycopersici (Acarina: Eriophyidae)] has become one of the more important pests of greenhouse tomatoes in northeastern North America. As a first step toward developing a biological control strategy for the TRM, our objective has been to test the potential of already commercialized mite predators. In laboratory experiments, voracity of Chrysopa carnea
(Neuroptera: Chrysopidae), Phytoseiulus persimilis (Acarina: Phytoseiidae), and Amblyseius cucumeris (Acarina: Phytoseiidae) was determined for egg, immature, and adult stages of the TRM. The first two predator species did not prey on TRM, whereas A. cucumeris fed on each of the life stages of the eriophyid mite. Further experiments showed that A. cucumeris was able to develop and reproduce when feeding on TRM. Implication of these results for controlling TRM in greenhouses is discussed with respect to predator specificity and prey suitability.

THE USE OF PROPANE BURNERS FOR CONTROL OF ANNUAL BLUEGRASS (POA ANNUA L.) IN SOD PRODUCTION

Marc Laganière* and Yves Desjardins, Centre de Recherche en Horticulture, Pavillon de l'Envirotron, Université Laval, Ste-Foy, Québec G1K 7P4, Canada

At present, there is no herbicide registered for use in Canada to control annual bluegrass in sod production. Under serious infestations, aesthetic qualities are reduced and sod harvest becomes more complicated. The efficiency of propane burners to control annual bluegrass was tested in a trial initiated in Spring 1993. Specific objectives were to determine the appropriate period for treatment application and the heat intensity required for optimal control. Twenty-one plots $(13 \times 3$ $\mathrm{m}$ ) were treated with a conventional burner; a similar group was treated with a pipe burner. In addition to an untreated check, the combination of two tractor-burner speeds ( 3.6 and $\left.5 \mathrm{~km} \cdot \mathrm{h}^{-1}\right)$ and three gas pressures $(20,30$, and 40 psi) made up the seven treatments. Randomized complete blocks were used and each treatment was replicated three times. The sod recovered well from all heat treatments. After 3 weeks, the best heat treatment reduced the annual bluegrass population by $70 \%$. Unfortunately, this reduction lasted for about 1 month, after which the annual bluegrass population recovered. At best, weed population was reduced by $40 \%$ when evaluated in mid-September. Another trial is planned to identify environmental and edaphic factors that may reduce the effectiveness of heat treatments in controlling annual bluegrass in sod production.

\section{CHANGES IN SUGAR CONTENT IN CUT ONION DURING STORAGE}

Mylène Blanchard*, Francois Castaigne, and Joseph Makhlouf, Department of Food Science and Technology, Laval University, Québec G1K 7P4, Canada

Our purpose was to study the impact of controlled atmosphere (CA) on respiration of and changes in sugar content of diced onions. The onions were peeled, diced, washed, disinfected, and centrifuged before storage for 12 days under gas mixtures of $21 \% \mathrm{O}_{2}$ and $0 \% \mathrm{CO}_{2}$ (air), $2 \% \mathrm{O}_{2}$ and $0 \% \mathrm{CO}_{2}$, and $2 \% \mathrm{O}_{2}$ and $10 \% \mathrm{CO}_{2}$. Every 4 days, respiration rate and sugar content (total, sucrose, fructose, and glucose) were determined. Carbon dioxide-enriched atmosphere limited respiration rate and sucrose depletion, whereas the mere reduction of $\mathrm{O}$, had no effect. Reducing sugar contents remained constant during storage regardless of the treatment.

\section{MOLECULAR CHARACTERIZATION AND TRANSIENT EX- PRESSION OF MAIZE SUS1 PROMOTER}

Xiao-Fang Huang*. Binh Nguyen-Quoc, and Serge Yelle, Centre de Recherche en Horticulture, Département de Phytologie, Université Laval, Ste-Foy, Québec G1K 7P4, Canada

Sucrose synthase (SS) is one of the key enzymes in plant carbohydrate metabolism. In maize, this enzyme is encoded by two genes, Shl and Susl. We have isolated and determined the 5'-upstream sequence of maize Sus 1 gene and compared it with the corresponding sequence in Shl gene. Sequence analysis revealed that there was a weak homology between the two promoters and no common sequence elements were found. To understand the differential regulation of the expression of the two genes, we constructed chimeric GUS fusions using the two promoters of SS genes. By using the biolistic system, we delivered these constructs into various plant tissues, and their transient expression was studied. Our results showed that the two promoters of SS genes directed tissue-specific expression in the same way that the two genes are expressed in vivo. The effectiveness of the expression of the constructs was recorded by counting the total blue expression units (blue spots) per shot and by fluorometric assays. High levels of 
GUS activity were detected in the immature embryos, young coleoptiles, and heterotrophic young leaves bombarded with the Sus-GUS construct. More than 100 expression units were observed in these tissues. Compared with the transient expression of the $35 \mathrm{~S}$ promoter in the same tissue, Sus promoter activity was twice as high. Strong Sus-GUS expression was also detected in the aleurone cells of developing kernels. In contrast, the Sh-GUS construct was expressed only in the endosperm with an activity twice as high as that of SusGUS and 35S-GUS in the same tissue. The results will be discussed in terms of the physiological roles of the two SS isozymes in plant tissues.

ANTIFUNGAL CONSTITUENTS OF CHENOPODIUM PROCERUM (CHENOPODIACEAE) HOCHST EX MOQ

Chantal Bergeron*. Andrew Marston, Etienne Hakizamungu, and Kurt Hostettmann, Institut de Pharmoacognosic et Phytochimie, Ecole de Pharmacie, Université de Lausanne, Lausanne, Switzerland

Dried ground aerial parts were extracted successively with dichloromethane and methanol at room temperature. Antifungal activity was determined by a TLC bioassay using Cladosporium cucumerinum. Four compounds were isolated from a dichloromethane extract by different chromatographic techniques (silicagel CC, Sephadex LH-20 gel filtration, and low-pressure LC on Diol): the isoflavones irilin A and irilin B, the flavonone dihydrowogonin, and sesquiterpene pygmol. The latter three were antifungal. The minimal amount that inhibited the fungal growth of $C$. cucumerinum was $5 \mu$ for these compounds. Four flavonol glycosides were obtained from the non-fungicidal extract by Sephadex LH-20 gel filtration and centrifugal partition chromatography. The structures of the compounds were elucidated by spectroscopic methods (UV, ${ }^{1} \mathrm{H}$ NMR, ${ }^{13} \mathrm{CNMR}, \mathrm{MS}$ ).

COMPARISON OF SIX LOCAL STRAWBERRY CULTIVARS TO MEXICAN BERRIES FOR INDUSTRIAL JAM PRODUCTION Shahrokh Khanizadeh ${ }^{* 1}$, Jacinthe Fortin ${ }^{2}$, Michel J. Lareau ${ }^{3}$, and Deborah J. Buszard $_{2}^{ \pm}$Agriculture Canada, 430 Boulevard Gouin, StJean-sur-Richelieu, Québec J3B 3E6, Canada; ${ }^{1,4}$ Plant Science Department, McGill University, Ste-Anne-de-Bellevue, Québec H9X 3V9, Canada; ${ }^{2}$ Food Research and Development Centre, Agriculture Canada, 3600, Casavant Ouest, Saint-Hyacinthe, Québec J2S 8E3, Canada

Frozen fruit of five locally grown strawberry cultivars and a recent introduction were compared to imported berries for making jam. Line scales were used to evaluate sensory attributes. Cultivars differed only in acidity, fruity flavor, and berry integrity. Jam produced with Quebec-grown berries was less acidic and more fruity tasting than that made from imported Mexican berries. 'Kent' had better fruit integrity than Mexican berries, followed by 'Chambly', 'Midway', 'Bounty', and 'Glooscap'. Frozen local strawberries were preferred to Mexican berries for making jam. Overall impression was better for Quebecgrown strawberries with the exception of 'Midway', which had lower overall impression than Mexican berries.

COMPARISON OF TWO METHODS OF DETERMINING ACHENE NUMBERS ON STRAWBERRIES

Shahrokh Khanizadeh ${ }^{* 1}$. Clément Vigneault ${ }^{2}$, and Deborah Buszard ${ }^{3}$ Agriculture Canada, 430 Boulevard Gouin, St-Jean-sur-Richelieu, Québec J3B 3E6, Canada; ${ }^{1,3}$ Plantt Science Department, McGill University, Ste-Anne-de-Bellevue, Québec H9X 3V9, Canada

Development of strawberry fruit depends on the number of fertilized achenes on the surface. The achenes are distributed on the receptacle surface in a pattern of more or less regular rows, spirally arranged. The number of achenes is determined by 1) counting the number of achenes per square centimeter of surface on ripe berries; 2) weighing the achenes after separation from the receptacle; or 3) counting the number of achenes after pressing the fruit between two layers of glass. The above methods are laborious and time-consuming. We, therefore, described anew semi-automated method (Image Analysis System, IAS) as an alternative to the above procedures. The IAS is capable of grouping the achenes into two or more categories based on their size (sound or aborted), surface area, color, volume, etc. This will facilitate the study of the relationship between achene number and fruit weight in strawberry.

\section{Symposium}

ENHANCED RESISTANCE OF TOMATO PLANTS TO FUSARIUM OXYSPORUM F.SP. RADICIS-LYCOPERSICI UPON TREATMENT WITH CHITOSAN: CYTOCHEMICAL ASPECTS OF INDUCED RESISTANCE

Nicole Benhamou, Département de Phytologie, Université Laval, SteFoy, Québec G1K 7P4, Canada

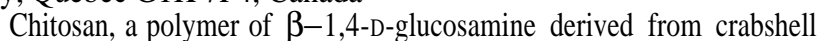
chitin, was applied to tomato plants before inoculation with the root pathogen Fusarium oxysporum f.sp. radicis-lycopersici. Whether chitosan was applied by leaf spraying, root coating, or seed coating, it reduced the number of root lesions caused by the fungus and increased the formation of physical barriers in infected root tissues. Formation of wall appositions such as papillae and occlusion of xylem vessels with coating substances were among the most typical features of host reactions. Another type of response was the accumulation of globular structures and electron-opaque masses in host cells neighboring colonized areas. Gold cytochemistry revealed that callose and lignin-like material were the main structural compounds induced in response to chitosan treatment and infection. Biochemical investigations showed that PR proteins as well as enzymes of the secondary metabolism were also significantly induced. The potential of chitosan as a biocontrol compound is discussed in relation to its ability to enhance plant protection against root pathogens.

CONTROL OF THE COLORADO POTATO BEETLE WITH AUGMENTATIVE RELEASES OF THE STINKBUG PERILLUS BIOCULATUS

Conrad Cloutier, Département de Biologic, Université Laval, Québec G1K 7P4, Canada

Tests in experimental plots over two seasons have shown that it is possible to obtain excellent control of eggs and larvae of the Colorado potato beetle (CPB) (Leptinotarsa decemlineata) under Quebec growing conditions by augmentative releases of a generalist predator, the twospotted stinkbug P. bioculatus. The stinkbugs were mass-reared on CPB eggs and larvae in the laboratory, and were released as second or third instar nymphs at the time of peak beetle oviposition. They were introduced manually at ratios of 2-4 predators : beetle egg mass in plots comprising $\approx 1000$ 'Kennebec' potato plants. Short-interval sampling after introduction indicated good rates of establishment and survival of the released $P$. bioculatus nymphs. Analysis of CPB egg recruitment and mortality indicated high rates of destruction of $\mathrm{CPB}$ eggs by the stinkbug. Egg destruction was followed by significant predation of late-instar bugs on CPB larvae, resulting in significant reductions of $\mathrm{CPB}$ prepupal and adult densities, and excellent foliage protection in treated plots compared to untreated controls. The results will be discussed with reference to traits of $P$. bioculatus that make it a good candidate for biocontrol of the $\mathrm{CPB}$, and to problems yet to be resolved before augmentative releases of the predator can be used as an integrated pest management tactic in larger scale potato production.

\section{ALTERNATIVE MANAGEMENT TECHNIQUES FOR OR- CHARDS}

Warren C. Stiles, Department of Fruit and Vegetable Science, Cornell University, Ithaca, NY 14583

Concerns about the impacts of agricultural practices on the environment dictate that all management techniques must be examined from the perspective of minimizing such impacts. Integrated pest management practices such as scouting, use of biological controls, improvement of pesticide application techniques, tree-row-volume spraying, and consideration of the environmental impact of alternative chemical controls offer opportunity for minimizing the adverse impact of pesticides. Improved spray equipment with canopy sensors and spray recovery systems improve deposition and reduce pesticide waste. Applying nutrients on the basis of need as indicated by leaf and soil analyses offers the best means of assuring optimal crop perfor- 
mance and minimizing the potential for contamination of surface and ground water supplies. Soil management practices must be evaluated for their potential to minimize soil erosion and competition, and for their potential contribution to pest management. Ground covers that are nonsupportive of nematodes, disease, or insect pest populations merit additional research. Methods for managing ground covers with low rates of growth regulators or herbicides to minimize invasion by problem weeds, reduce the need for mowing, and regulate competition, while retaining their beneficial attributes in minimizing soil erosion and maintaining soil structure, would be advantageous to orchardists and the environment.

THE DEVELOPMENT OF CLOSED GROWING SYSTEMS IN THE NETHERLANDS AS A MEANS TO REDUCE ENVIRONMENTAL POLLUTION

W. Voogt. Glasshouse Crops Research Station, 2670 AA, Naaldwijk, The Netherlands

In the Netherlands, many crops in protected cultivation changed from soil to soilless culture in recent years. The reasons for this development were problems with soil sterilization and better growth control with soilless culture, which led to considerable yield increases. However, the growing systems used, with free leachate drainage, contribute highly to pollution of the ground and surface water with minerals ( $\mathrm{N}$ and $\mathrm{P}$ ). To reduce this emission, closed growing systems were developed, i.e., systems with recirculating nutrient solutions. Inherent to these systems, however, were problems such as the rapid spread of pathogens in the root environment. Methods were developed for disinfestation of the nutrient solution. Salt accumulation was also a concern, the concentrations of ions in the water used for closed systems must be lower than the uptake capacity of the plants. To avoid depletion and accumulation of certain nutrients. the addition of nutrients should be adapted to the demand during the cropping period. For this purpose, nutrient solutions and guidelines for adjustments during the cropping period were developed for several crops.

\section{UTILIZATION OF BIOSOLIDS IN HORTICULTURE}

Chantal J. Beauchamp*, Yves Desjardins, Serge Yelle, and André Gosselin. Départment des sols et de Phytologie, Centre de Recherche en Horticulture, Université Laval, Québec G1K 7P4, Canada

Canadian environmental policies are aimed at reducing by $50 \%$. the quantities of refuses intended for landfill by year 2000. In this perspective, landspreading and composting biosolids have been investigated as solutions. Paper sludges, wood wastes, and municipal solid wastes (MSW) are important components of landfill biosolids, but they are attractive by-products for agricultural use. Research projects were initiated to characterize the paper sludges produced by Daishowa Co. in Quebec City, wood wastes produced by Hydro-Quebec, and MSW composts produced from waste treatment at RITDM (Chertsey) and Conporec (Sorel). De-inked paper sludge and wood wastes have been landspreaded for growing potato and landscaping, whereas composted paper sludges have been evaluated as part of potting media for growing greenhouse plants and landspreaded for turfgrass production. The chemical and biological characteristics of these biosolids were investigated for their fertilization potential and their effect on plant growth.

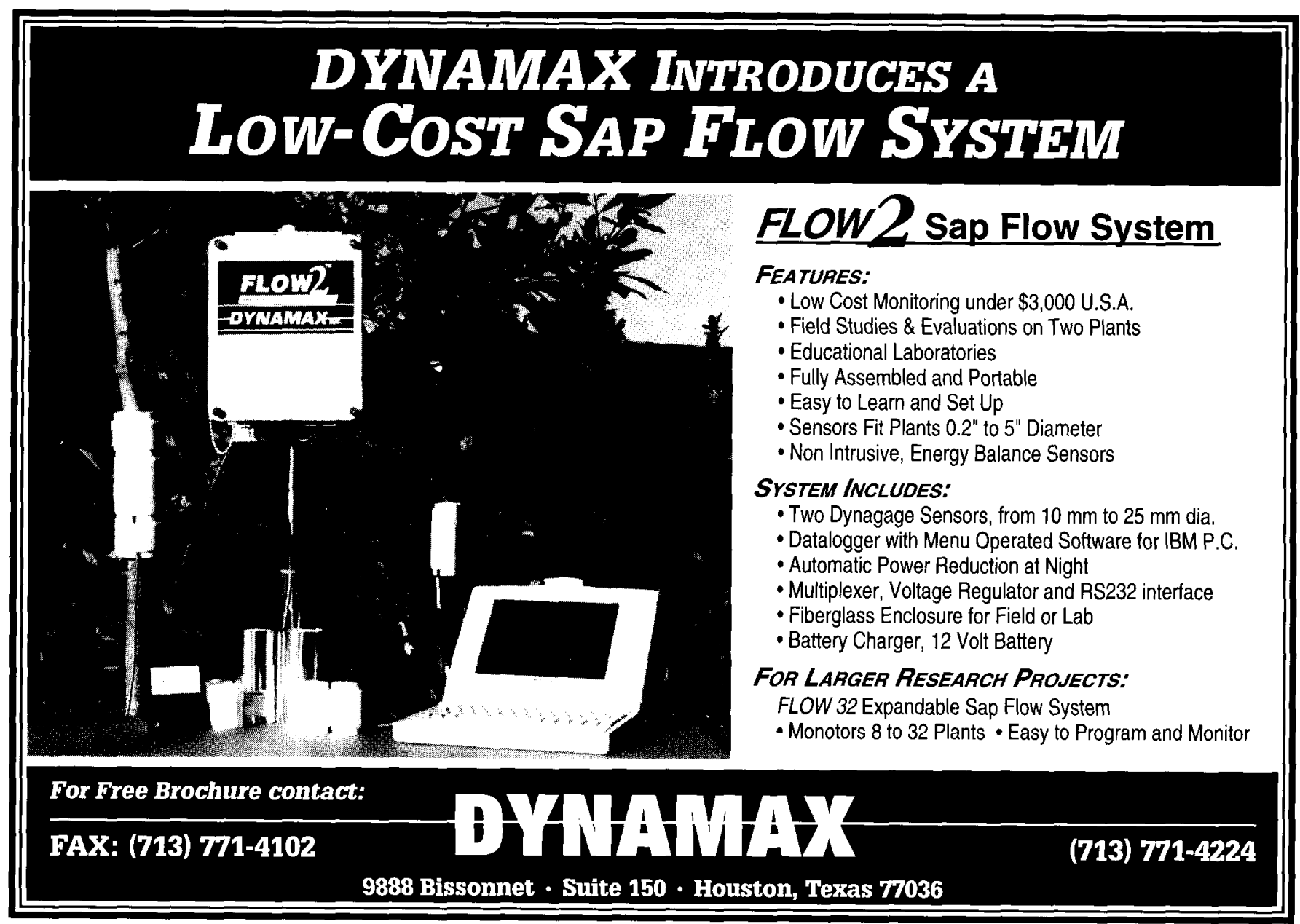

